Anne Schjoldager*

\title{
An Exploratory Study of Translational Norms in Simultaneous Interpreting: Methodological Reflec- tions ${ }^{1}$
}

\begin{abstract}
This paper discusses some possibilities that the theory of translational norms (Toury 1980) may offer in connection with research into simultaneous interpreting. After a brief discussion of the concept of translational norms, I explore how this concept may be useful in interpreting research in general. I then proceed to discuss and criticize the set-up of my own project on simultaneous interpreting and translation - especially how progressive aspect was originally used as a focus of analysis. I conclude by demonstrating how the theory of translational norms has been a useful methodological tool in the analysis of my data. One result is the discovery that certain translational norms seem to be peculiar to simultaneous interpreting - for instance norms regarding what one ought to do in connection with capacity saturation.
\end{abstract}

\section{Introduction}

Though the theory of translational norms, first proposed by Toury (1980), has been influential in translation studies for quite some time now, this methodological and theoretical framework seems to have had little impact on interpreting research. Most theory-forming work on interpreting, which did not start till the late 1960s (Gile 1994:149), seems to have been preoccupied with the activity as a process of reformulation or as an extraordinary capacity for shared attention. An example of the former is la théorie du sens, the theory of "sense" or "intended meaning", proposed by Seleskovitch in 1968 (eg Seleskovitch 1978a). An example of the latter is Gile's Effort models (eg Gile 1991).

1 Other versions of parts of this article are found in Schjoldager (forthcoming) and in Schjoldager (1994b).

* Anne Schjoldager

Department of English

The Aarhus School of Business

Fuglesangs Allé 4

8210 Aarhus V(DK)

Hermes, Journal of Linguistics no. 14 - 1995 
Thus, to my knowledge, descriptive work on translational norms in interpreting is rare. Until recently, very few scholars had touched upon the topic at all. Shlesinger (1989) and Harris (1990) were probably the first interpreting scholars to discuss the concept of translational norms in interpreting - both in Target, a journal that has as one of its explicit aims to focus on translational norms. Shlesinger gives a brief account of methodological problems that one might encounter when trying to extend the theory of translational norms to interpreting research. Though she definitely appreciates that norms must play a part in the interpreting process, she concludes that, due to the numerous difficulties involved in their extrapolation, it is too early to start speculating about the nature of such norms ${ }^{2}$. In a response to these views, Harris argues that it is indeed possible to pinpoint existing norms in the interpreting community, but whereas Shlesinger's discussion is mainly concerned with methodological problems, Harris merely supplies a list of normative formulations.

Recently a few scholars seem to have found the concept of norms useful in studies of interpreters in institutional settings. Taking his starting point in Descriptive Translation Studies (DTS) ${ }^{3}$, Jansen (forthcoming) describes a small-scale empirical study of the "interaction between institutional structures and actual translation strategies" in a Dutch courtroom. A different, but related, example seems to be Wadensjö (1992 and this volume). Though her theoretical framework is sociology and anthropology - especially Goffman's (1981) analysis of intermediary roles - rather than translation studies, she, too, takes the concept of norms into account in her analysis.

\section{The Concept of Translational Norms in Interpreting Research}

According to Toury (1978:51) $)^{4}$, translation is subject to various kinds of constraints. These constraints may be described in a continuum

2 In this context, it may also be interesting to note that the concept of translational norms apparently has not influenced Shlesinger's own work on simultaneous conference interpreting. See for instance Shlesinger (1990) and (1994).

3 DTS is closely linked with the so-called "Manipulation School" - see for instance Schjoldager (1994a).

4 For a brief discussion of Toury's methodology explained in the published version (1980) of his dissertation from 1977, see also Vanderauwera (1982). 
between two extremes: objective, relatively absolute rules and fully subjective idiosyncrasies. Translators seem to be influenced mainly by the middle ground of this continuum. Thus, they behave according to constraints which are neither completely codified nor completely arbitrary. These constraints in the middle ground of the normative scale are norms.

Toury (1980) distinguishes between preliminary, initial and operational norms. Preliminary norms concern "the very existence of a definite translation 'policy' along with its actual nature and those questions related to the 'directness' of the translation" (Toury 1978:53). Initial norms govern the translator's overall strategy: S/he can either opt for adequacy, which emphasizes adherence to source-system norms or acceptability, which emphasizes adherence to target-system norms. Operational norms concern actual decisions made during the process of translating.

One obvious question in this connection must be: Is interpreting a norm-governed activity? I think there can be no doubt that, as a behavioural activity, interpreting must also be governed by norms. Naturally, interpreters, too, need norms to help them select appropriate solutions to the problems they meet. There is, of course, no reason to think that all interpreting performances would be totally predetermined, with no room for personal decision-making. Just as it would be absurd to assume that they would be totally unique and ungoverned by norms. Clearly, there is no such thing as to 'just interpret', because this would merely be a case of adopting the "standard norm" (Hermans 1991:165).

According to Hermans (1991:167), there are at least three major models that supply the translator's norms: (1) the source text, (2) the relevant translational tradition, and (3) the existing set of similar originals in the target culture. These models seem to be equally true for interpreters: (1) Some norms may depend mainly on the source speech itself, as well as its context and purpose. (2) Some are drilled into students while still at school, or are developed out of professional experience, for instance when the interpreter listens to a colleague at work. This situation is very likely, as professional conference interpreters are supposed to work in pairs. (3) They may also depend on the nature of speeches (ie originals) that the interpreter has heard in similar contexts.

According to Toury (1978:57), for the scholar searching for these underlying norms, there are two major sources: textual norms, which 
are found by means of a source-target comparison, and extratextual norms, which are found in explicit, normative statements in the literature about translation. As far as the identification of textual norms is concerned, various methodological difficulties may be encountered that are peculiar to interpreting research. The main difficulty probably lies in the lack of accessible interpreting performances. Unlike literary translations, which are usually meant for mass production and may be read by anyone interested, interpreting performances are meant for the present audience only and are rarely accessible afterwards. For one thing, as Shlesinger (1989:114) notes, AIIC (Association Internationale des Interprètes de Conférence), the prestigious International Association of Conference Interpreters, "is averse to having speakers or conference organizers record interpreters". One consequence of this inaccessibility 5 is that it may be difficult for the researcher to procure a corpus large enough to distinguish general from idiosyncratic tendencies (Shlesinger 1989:113).

Another methodological problem lies in the fact that, when investigating interpreting performances, the scholar may invariably interfere with the process. Literary translators are probably fully aware that their texts may afterwards be scrutinized and compared with the source text, and this knowledge probably does not change their habitual translational behaviour in any significant way. But interpreters who find themselves the object of scientific analysis may start to behave contrary to their habits. This, again, affects the representativity of the corpus - be that in a real conference where output is recorded or, which is even more artificial, in an experimental and didactic study such as mine.

As far as the identification of extratextual norms is concerned, this is only a little harder in connection with interpreting than with translation. Though there are more books on written translation than on interpreting, it should not be too difficult to find normative literature on interpreting. An example of this is Harris' norm of the "honest spokesperson". In accordance with this norm, interpreters should: ".. reexpress the original speakers' ideas and the manner of expressing them as accurately as possible and without significant omissions, and not mix them up with their own ideas and expressions" (Harris 1990:118).

5 See also Gile, this volume (3.c), regarding interpreters' reluctance to allow researchers to record and analyze their performances. 
However, when investigating interpreting - especially simultaneous interpreting - we should probably also account for the high degree of complexity involved in the task. One way to do this would be to consider processing conditions such as time pressure, the oral medium and the fact that interpreting requires a capacity for attention-sharing. Regarding the latter factor, Gile's Effort model of simultaneous interpreting (eg Gile 1991) shows how the process consists of a set of competitive operations. Because these operations consist of conscious, deliberate and often exhausting components, they are called Efforts. There are - at least - three such Efforts: (1) listening to and analyzing the source speech, (2) producing a target speech, and (3) short-term memory for storage and retrieval of information. Each Effort has a particular processing capacity requirement, depending on the task at hand. If the interpreter does not possess the required amount of processing capacity, the task becomes difficult or even impossible.

Quite clearly, we shall always find it difficult to ascertain to which degree processing conditions determine the interpreting performance. Thus, perhaps the interpreter opts for one solution, following one set of norms, but cannot carry it through because of capacity saturation. One way of dealing with this methodological problem could be to introduce a different kind of norm - one that is peculiar to interpreting. This norm could for instance govern what the interpreter ought to do - or is allowed to do - when the task becomes difficult or impossible. An example of this is mentioned below (6.5).

The rest of this article deals with my own project on simultaneous interpreting and translation. First, I give a brief outline of the empirical data. Then, I discuss the preliminary objective, which was didactic, and methodological problems in connection with the set-up of the investigation. Finally, I exemplify how a search for translational norms may proceed in connection with my corpus.

\section{Subjects}

The project is based on an empirical investigation into simultaneous interpreting and translation. The subjects, who delivered the target texts, were divided into four groups according to level of competence and medium of translation. The following is a graphic representation of the four groups: 
Group-I subjects are fifth-year CLM (candidatus linguae mercantilis) students at the Århus School of Business, who have just finished a compulsory one-year course of interpreting. The CLM programme is a master's programme which mainly offers translator-relevant courses, but it also includes some interpreting training - simultaneous as well as consecutive. I therefore feel justified in regarding these subjects as 'beginners' in the field of interpreting. Group-II subjects are students at the six-month postgraduate course of conference interpreting at the Copenhagen Business School. It is the explicit aim of this full-time course to ensure that those candidates who pass the final exam, which is supervised and approved by the European Commission, have acquired high-level professional skills and ethics in conference interpreting (see for instance Fluger, Zoëga \& Aarup 1991:10). As the group-II subjects, who previously had to pass a rigorous entrance exam, are just about to enter the final exam, I feel justified in regarding these subjects as 'advanced' in the field of interpreting.

Group-III subjects are third- and fourth-year CLM students at the Århus School of Business, who have only just started learning about professional translation. I therefore regard these subjects as beginners in the field of translation. Group-IV subjects are professional, practising translators and they are therefore characterized as 'advanced' in the field of translation.

\section{Procedure}

Late 1990, two newspaper texts were selected. The contents of these texts formed the basis of the source texts of the investigation. The 
Danish text was an article published on 30 December 1990 in JyllandsPosten, a major quality paper in Denmark. In this article, the journalist critically assesses the situation in the Soviet Union and expresses fears that Mr Gorbachev, the then President of the Soviet Union, might be losing control. The English text was a full-page advertisement in the Observer, published on 18 November 1990. In this advertisement, Amnesty International tries to persuade readers to become members. Citing horrid details, it describes how the Iraqi government systematically gasses the Kurdish region in Iraq.

For the purpose of the investigation, a simulated situation was constructed: A Danish "society for ordinary people wanting to discuss important issues in the world today" has invited two guest speakers. The idea is that the views expressed by these guest speakers should function as the starting point of the ensuing discussion. Both speakers have chosen their own topics. The first speaker, a Danish journalist from Jyllands-Posten, has chosen to talk about the situation in the Soviet Union. The second speaker represents Amnesty International in London and has chosen the Kurdish predicament in Iraq as her topic. The audience consists of Danish members of the society as well as English-speaking guests. That is why the speeches are interpreted simultaneously into Danish and English, respectively.

Mid-January 1991, the two source speeches were given 'live' - with few deviations from the manusript - to the group-I subjects (beginner interpreters) in the interpreting laboratory of the Arhus School of Business. The interpreting performances were recorded, and so were the source speeches. Then, in the interpreting laboratory of the Copenhagen Business School, the tape recording of the source speeches was played to the group-II subjects (advanced student interpreters), who also interpreted simultaneously. Finally, in March 1991, the source speeches were transcribed. A few oral-language features, such as false starts and throat-clearing sounds, were erased. The written form of the speeches was then given to the group-III subjects (beginner translators) and the group-IV subjects (professional translators) to translate. The translators, who were asked not to use dictionaries and reference books, worked at home and in their own time. All subjects were informed of the simulated situation (ie a Danish society with guest speakers), but none of the subjects were given explicit instructions as to target-text purpose. Actually, they were simply asked 'to just translate'. 


\section{Preliminary Objective and Assumptions}

The preliminary objective of this collection of data was didactic: What had beginners of simultaneous interpreting learned to do and what did they still need to learn in order to live up to professional standards? What had advanced student interpreters learned and what did they still need to learn? How did the behaviour of these two groups compare with that of translators, both beginners and professionals? This preliminary objective was based on three interlinked assumptions. I shall now discuss each of these in turn, and I shall show why they had to be modified or even abandoned.

\subsection{First Assumption: Similar Objective, Different Process}

The first assumption was greatly inspired by a study carried out by Dollerup, Fluger, and Zoëga, who argued that interpreting and translation are different, but similar, kinds of "interlingual transfers" (Dollerup, Fluger, \& Zoëga 1992:44). In line with this, I defined the interlingual transfers of my investigation in terms of their assumed objective: a reproduction in one language of a message uttered in another language (see also Dollerup 1978:11). Consequently, I assumed that differences in the performances could be explained by differences in working conditions. I described these various working conditions by means of factors related to medium and time (see also Dollerup 1978:19, and Lenstrup \& Zoëga 1987:17).

The task of the interpreter subjects was definitely very complex: Due to the oral medium, they could neither regress in the source texts nor revise their target texts, and, due to the simultaneity of the task, they had to share their attention between Gile's three Efforts: (1) understanding a message in one language, (2) reproducing this message in another, and (3) storing and retrieving information in their short-term memories, as already explained. The translator subjects suffered none of these complications.

Many scholars seem to share the idea that translation and interpreting are related activities. A good example of this is the existence of a German inclusive term, Translation, for both interpreting and translation, first suggested by Kade in Leipzig in the 1960s, and since used by many German scholars - notably Vermeer, Reiss, and Holz-Mänttäri (see for instance Pöchhacker 1992, and this volume). In continuance of 
this, Pöchhacker (1993:54) suggests that a science of translation and interpreting (Translationswissenschaft) would consist of two subdisciplines: (1) translation studies (Übersetzungswissenschaft) and (2) interpreting studies (Dolmetschwissenschaft). Whereas some specific models and concepts would apply exclusively to either of these two areas, at least some theoretical concepts must be thought to apply equally to both of them. Pöchhacker refers to this shared theoretical framework as a general theory of translation and interpreting (allgemeine Translationstheorie).

Other scholars have similar ideas about the relationship of translation and interpreting. Seleskovitch (1978b:333), an influential interpreting scholar, agrees that the "basic process" is the same. This basic process seems to be governed by the fact that "sense" (le sens) - which is the contextual, deverbalized meaning or message - functions as the guiding principle in both tasks (Seleskovitch 1978b:335). In the same way, though she, too, emphasizes that they definitely are not identical, Aarup (1993:169) writes that the two tasks are related and that the "main difference between (written) translation and (oral) interpreting is the time factor".

However, though I am still convinced that interpreting and translation must be seen as related activities, I now think it would be more interesting to look at my corpus from a somewhat different angle than previously. Rather than working on the assumption that interpreters and translators per se are trying to achieve similar goals, I shall now try to discover to which extent the various subjects in my investigation behave in similar ways. I might therefore ask questions such as: Are there similarities in their choice of translational strategies? Are certain norms shared by all subjects? Are certain norms peculiar to one group?

\subsection{Second Assumption: Less-than-perfect Interpreters}

The second assumption was that different working conditions would invariably lead to differences in quality - both in terms of source-text fidelity and in terms of target-language acceptability. Thus, as interpreters are disadvantaged by strenuous working conditions (time and medium) and by an extremely complex process, I expected my interpreter-subjects to produce less-than-perfect target texts, whereas I expected the translators to produce all-but-perfect results. In fact, originally I intended the translations merely as a sort of checklist: What 
could (or should) the interpreters have said if they had had as much time and as much source-text access as the translators?

Harris' (1990:117) reference to a story concerning the proceedings of the Canadian Parliament (Hansard) seems to suggest that this second assumption was correct. In the early 1970s, Harris explains, it was proposed to replace the regular translators, who translated the Parliamentary proceedings, with secretaries who would simply transcribe tape recordings of what the simultaneous interpreters had said during the meetings. But it very soon became evident that it was far more timeconsuming first to transcribe the interpreters' translations and then to revise them to publishable standards than to translate directly from edited transcripts of the original speeches.

This Canadian experiment is interesting in at least two ways: Firstly, it is interesting that the experiment was devised in the first place, because it suggests that the inventor must have regarded interpreting as an oral variant of translation. In other words, once it had been transcribed, the inventor must have expected the oral output to fulfil the same objective as a written translation of the proceedings - an expectation quite similar to my first assumption, discussed above. Secondly, the fact that this procedure proved to be a waste of time is interesting because it seems to indicate that, when judged by written standards, interpreters tend to produce less-than-perfect target texts.

There are two reasons why my assumption concerning differences in quality was hasty. The first one has to do with the impossibility of comparing oral and written performances directly. The second reason concerns the risk involved in defining one type of interlingual transfer as inferior to another. Firstly, it is difficult to find parameters which are equally applicable to oral and written performances. Usually, when wishing to compare the two media, we choose to transform the oral performances into the written medium in the form of transcripts. But this is dangerous because we then also tend to judge the oral performances by written standards (see for instance Jacobsen \& Skyum-Nielsen 1988:132). Consequently, oral performances that were perfectly understandable and acceptable to the listeners in the situation of communication may suddenly seem flawed and incomprehensible when judged in the written form.

Secondly, as a consequence of this written bias, it may even be impossible to establish which type of interlingual transfer is generally 
the more successful. The point to note is of course that interpreting performances need to be assessed according to different criteria from those of translation (see for instance Gile 1993:74). Therefore, to revert to the Canadian experiment discussed by Harris, the Parliamentary interpreters may well have been regarded by their listeners as just as successful in achieving their goal as the subsequent translators were by their readers in achieving theirs.

\subsection{Third Assumption: Progressive Aspect as Focus of Analysis}

The third assumption was that it would be possible to concentrate on one linguistic problem whose successful or unsuccessful solution could then be used for generalizations about the nature of the performances. In formulating this third assumption, I was inspired by three empirical investigations carried out at the Copenhagen Business School. In all these investigations, syntactic differences between English and Danish were used as the starting point for generalizations about interpreting and/or translation.

Fluger (1983), an interpreting scholar, describes a small-scale investigation into simultaneous interpreting. In this investigation, Fluger is mainly interested in sentences in which the word order of the source text cannot or should not be copied by the interpreters. To this end, she concentrates on the translation of six utterances in the English source speech which are supposed to be syntactically problematic when interpreted into Danish. One of her examples, therefore, deals with the fact that a Danish translation (TT) of the following source-text (ST) utterance would require inversion, as shown below:

1) ST: "In November 1982, 9912 Europeans ..were",

TT: "I november 1982 blev 9912 europæere .."

In other words, Fluger concentrates on detecting incidents in which the interpreters have uttered syntactically incorrect Danish sentences such as this:

2) TT: *"I november 19829912 europæere .. blev"

Lenstrup \& Zoëga's (1987) investigation is more extensive. Their investigation deals with the translation and simultaneous interpreting of a speech held by Mrs Thatcher at a party conference in 1981. In this 
English source text, they concentrate on renditions of adjectival participle clauses in the source text, such as "goods produced abroad .." or "the dose required ..".

Taking her starting point in psycholinguistic research into second language acquisition, Mondahl's (1989) PhD thesis thoroughly investigates (written) translation processes by means of introspection (loudthinking) and retrospection (interviews). Mondahl's general interests lie with linguistic knowledge (mainly explicit grammar rules), but, in the analysis, she focusses on the rules governing her subject's way of translating Danish future reference into English.

Inspired by these three investigations, I, too, decided to focus on syntactic differences between English and Danish. In my case, the focus was on various incidents of progressive 'meaning'. From my experience as a teacher of English and from some literature on teaching English to Danes $^{6}$, I knew that the obligatory status of the aspect category in English is a particular problem for Danes who speak English as a foreign language. By analogy, I assumed that this would also be the case when Danish had to be translated into English and vice versa.

The grammatical notion of aspect concerns the manner in which a verbal action is experienced or regarded. By choosing either progressive or simple verb forms, English speaker/writers signal whether they see the action as being in progress or as completed. Usually Danish speaker/writers do not have to make this choice ${ }^{7}$. Therefore, as the marking of aspect in Danish is mostly optional, many Danish sentences may refer to progressive actions without any formal marking.

Furthermore, whereas English makes use of morphological means, ie the aspectual contrast between progressive and simple verb forms, markers of progressive aspect in Danish are fixed, lexicalized phrases. The following examples are Østergaard's (1979:94ff). I have added a close translation in square brackets and underlined relevant phrases.

3) "Peter sidder og $\underline{\text { ser }}$ fjernsyn"

[Peter is sitting and watching television]

6 See for instance Davidsen-Nielsen \& Færch \& Harder (1982:53), who write: "The obligatory status of the 'aspect' category in English presents a problem for the Danish learner, who is only used to marking for aspect when this is relevant".

7 See for instance Østergaard (1979:95), who writes: "The first thing to note about progressive aspect in Danish is that in all but a few cases the marking is optional". 
4) "Da jeg kom ind i stuen, $\underline{v a r}$ de ved at synge fødselsdagssangen".

[When I entered the room, they were singing the birthday song]

Consequently, if the following sentence, taken from my Danish source text, is to be translated into English, the translator/interpreter must consider whether a progressive 'meaning' is intended or not. As the two unmarked verb forms in Danish seem to denote temporary, incomplete, and overlapping actions (Leech 1987:22) - the first action ("brasede sammen") probably framing the second one ("drikke") - it would be natural to expect progressive verb forms in the English translation. A rough, close translation is given in square brackets afterwards. Relevant verbs are underlined. The item deals with the summit in Paris in November 1990 which marked the final demise of the Berlin Wall ${ }^{8}$. The language is clearly metaphorical. We shall revert to this source-text item below.

5) "Mens jerntæppet brasede sammen i øst, kunne man i alverdens medier se Gorbatjov drikke gravøl i vest".

[While the Iron Curtain was collapsing in the East, you could in all the world's media see Gorbachev drinking grave beer in the West]

Conversely, if the following clause, taken from my English source text, is to be translated into Danish, the translator/interpreter must consider whether the underlined progressive verb form should be translated by using a progressive marker in Danish (for instance "er ved at") or whether the progressive meaning cannot (or should not) be rendered syntactically at all. In cases such as the following example, most translation critics ${ }^{9}$ would probably prefer an unmarked Danish rendition ("foregår") of the English progressive verb form ("is going on").

6) ST: ".. to make you more aware of what is going on in the world today".

TT: ".. at gøre jer mere bevidste om, hvad der foregår $\mathrm{i}$ verden i dag"

8 This is an indirect reference to the signing of the Conventional Forces in Europe Treaty on 19 November 1990 at the Elysée Palace, Paris. Here heads of state and government from Europe and North America gathered to launch a new, postwar world order.

9 On aspect-related errors in a corpus of translations between Danish and English, see for instance Dollerup (1982:168), who writes: "In Danish target-language texts, calquing of extended tenses usually only makes for clumsy reading". 
In line with this, as it seems to violate standards of idiomatic Danish, most translation critics would probably categorize the following targettext item as a case of "hypercorrectness", using Dollerup's (1982:168) term.

7) TT: .. at gøre jer mere bevidste om hvad der *er ved at foregå i verden i dag.

On the basis of this discussion concerning the transfer of progressive 'meaning' between English and Danish, the intended methodology was as follows. As all my subjects were advanced speakers of English, I expected their de facto mastery of English grammar, including the reception and production of progressive aspect, to be almost perfect. Thus, I hypothesized, problems encountered in connection with the translation of progressive 'meanings' in Danish and English would not be due to lacking proficiency in the two languages, but would mainly be indicative of the translational process. I could then use these incidents as the starting point of my analysis.

However, at some point, I began to speculate whether the aspectual contrast between progressive and simple 'meanings' was really worthy of generalizations about the nature of the tasks. Perhaps these incidents were actually minor points in the translational process. So, perhaps, I was not really involved in translation studies, but rather in contrastive linguistics.

Furthermore, I was rather puzzled to find that so few subjects came up with solutions that seemed to reflect awareness of progressive aspect. Perhaps their de facto mastery of grammar was not that advanced after all; or perhaps I was wrong in thinking that progressive meanings had to be rendered at all. The following is an example of such a puzzling rendition. The subject is an advanced student of interpreting (group II), and we would therefore expect her not only to master progressive aspect, but also to master the simultaneous process. As explained in connection with example 5), here it would be natural to expect two progressive verb forms: one in the first part of the sentences ("was falling"), which is missing, and one in the second part ("drinking"). Be that as it may, it is difficult to ascertain what the missing progressive verb form in the first part tells us about the nature of simultaneous interpreting.

8) "As the Iron Curtain fell in eastern Europe, it was possible to see Gorbachev drinking the funeral celebratory drink in the west". 


\section{Methodological Problems}

As a consequence of the problems briefly discussed above, I discovered that the preliminary objective of my investigation was too ambitious: Firstly, my empirical material was not really suitable for generalizing about differences in the proficiency and behaviour of my subjects. The grouping was not sufficiently well-defined for that, and the task probably suited some groups better than others. I would therefore be better advised to place less emphasis on the differences between the two groups and adopt a more exploratory approach in order to look for regularities and irregularities in the corpus as a whole. Secondly, though my aim was to observe and not to assess the behaviour of the subjects, my choice of parameters was admittedly normative in Toury's sense. The whole methodology was probably too much characterized by an urge to assess quality, and my three assumptions were generally too categorical.

As the methodological framework of my investigation seemed insufficient and unsuitable for what I wished to achieve - namely to describe similarities and differences in the behaviour of my subjects - I was now in need of a different set of analytical tools. I then decided to use the concept of translational norms as a methodological tool. Though bearing in mind what was said above about certain shortcomings due to the researcher's possible interference in the translational process, I assume that my empirical material renders at least some background for generalizing about the subjects' translational norms. The following is a discussion of how this search for norms may proceed.

\section{An Exploratory Study of Translational Norms in Simul- taneous Interpreting}

As my investigation is carried out in an experimental and mainly didactic setting, I take it to be self-evident that preliminary norms (translation policy) should be disregarded in the analysis. I therefore assume that the norms employed by my subjects are initial norms (overall strategy) and operational norms (actual decisions during the translational process $)^{10}$. I shall search for these by means of a textual

10 In studies of authentic interpreting, all kinds of norms may be interesting. As regards the identification of preliminary norms, the scholar could for instance investigate what is selected for interpreting and in what ways. 
comparison between source and target texts. Furthermore, I explore the possibility that some norms may be peculiar to simultaneous interpreting and that they occur in connection with capacity saturation. The results of such a comparison of simultaneous-interpreting performances with their source speeches and with written translations of 'identical' source texts ${ }^{11}$ may generate hypotheses for further research involving real-life performances by professional conference interpreters.

\subsection{Methodological Framework}

In my search for textual norms, I follow the pattern of Toury's (1980) tripartite model. According to this model, there are three relationships between target and source texts: "Competence", which denotes theoretical, possible ways of translating a text, "performance", which is a description of existing translations, and "norms", which, as we have seen, is the intermediary level of more or less codified guiding principles. Thus, the analytical methodology of my investigation is as follows:

(1) Suggestion of theoretical models (competence).

(2) Source-target comparison (performance).

(3) Reconstruction of guiding principles in the translational process (norms).

\subsection{How to Translate "gravøl" into English}

In the rest of this article, I shall concentrate on possible and actual renditions of one small source-text item: the Danish word "gravøl", which stems from the source-text sentence already mentioned in examples 5) and 8):

9) "Mens jerntæppet brasede sammen i øst, kunne man i alverdens medier se Gorbatjov drikke gravøl i vest".

[While the Iron Curtain was collapsing in the East, you could in all the world's media see Gorbachev drinking grave beer in the West]

The Danish word "gravøl" refers to a tradition of grieving over the death of a person after his/her burial. Typically a spouse or another close relative invites the mourners home for refreshments. As the literal

11 'Identical' in linguistic and informational content, but of course not in medium and immediate context. 
meaning of this word is "grave beer", one would expect the mourners to drink beer, but other refreshments (especially coffee) are also considered traditional on these occasions. As a prevailing metaphor in the co-text of this source-text item is that the Cold War has 'died', the choice of "gravøl" is clearly significant. Furthermore, the choice is probably also ironical: Rather than mourning the 'death' of the Cold War, Mr Gorbachev seems to be rejoicing at it.

To produce a target-text item which renders all these connotations is certainly no easy task. In English-speaking countries, there are at least two ceremonies which resemble the Danish custom of drinking "gravøl", a 'wake' and a 'funeral reception', but none of these seem to cover all the connotations of the Danish term. Whereas the Danish gathering is a largely secular and informal affair which takes place after the religious ceremony, a 'wake' is a Catholic gathering to watch and grieve over a dead person on the night of the funeral (Longman 1992). The English word 'funeral reception' seems to correspond more closely to the Danish term, as it, too, is held after the burial and is a secular phenomenon, and as it also involves the serving of refreshments, but it does not have the informal connotations.

To sum up, in his/her rendition of "drikke gravøl", the translator/ interpreter may consider the following factors.

(1) Potential meaning: An informal gathering after the burial, which involves drinking (beer).

(2) Co-textual factor: A series of funeral metaphors.

(3) Intended meaning: Ironical.

\subsection{Theoretical Model of Translational Relationships}

Inspired by Delabastita (1989:199 and 1993:33), I employ five main categories of translational relationships or transformation categories. Though I would normally operate with various subcategories, these are only mentioned below under E/ Substitution. After a brief definition of each translational relationship, I give examples of various renditions of "drikke gravøl", if possible.

\section{A/ Repetition}

Target-text item bears formal relation with relevant source-text item. -"drink grave beer" 


\section{B/ Permutation}

Target-text item(s) is(are) placed in a different textual position from relevant source-text item(s).

- "beer drinking at the grave"

\section{C/ Addition}

Target-text item constitutes an addition to information given in relevant source-text item.

- "[drink grave beer] in the honour of the Cold War"

\section{D/ Deletion 12}

No target-text item bears direct relation with relevant source-text item.

- (No relevant example)

\section{E/ Substitution}

Target-text item bears no formal relation with relevant source-text item.

\section{E1/ Equivalent Substitution}

Source-text item is translated functionally.

- "at the wake"; "at the funeral reception"

\section{E2/ Paraphrastic Substitution}

Source-text item is translated functionally, but in an expanded and/or segmental way.

- "having a funeral celebratory drink"

\section{E3/ Specifying Substitution}

Source-text item is translated functionally and implicit information is made explicit.

- (No relevant example)

\section{E4/ Generalizing Substitution}

Source-text item is translated functionally, but conveys less information than relevant source-text item.

- "at the funeral"

\section{E5/ Overlapping Substitution}

Source-text item is translated functionally, but with a different viewpoint, so that target-text item conveys different information.

- "was sad"

12 Dam has thoroughly investigated condensing in consecutive interpreting, a strategy that bears some resemblance to my category D/ Deletion. See for instance Dam (1993). 


\section{E6/ Substitution Proper}

Target-text item bears little or no resemblance to relevant source-text item.

- "was orientating himself towards [the West]"

\subsection{Source-Target Comparison}

I shall now give a few examples of actual renditions in my corpus. Example 10) is an indication that the rendition of "gravøl" is indeed a problem. The subject, a beginner interpreter (group I), clearly has severe difficulties - presumably not only with the rendition, but also with the simultaneity of the task, ie a case of capacity saturation (eg Gile 1991). At first, she opts for an overall strategy of A/ Repetition, but then, in connection with "gravøl", she decides on a strategy of D/ Deletion. The left column illustrates how the source speech proceeds, the other the group-I interpreter's performance. The figures in parentheses and bold print indicate real time.

10)

Mens jerntæppet brasede

sammen i øst

kunne

man i alverdens medier

se Gorbatjov

While the iron car..pet

drikke gravøl i vest. (6.21)

(6.25) Det var tydeligt at Mikhail Gorbatjov [..]

was

ruined in the east

you could see-erm

Gorbachev

err

The next example is taken from the group of advanced interpreters (group II). Again, at first, the interpreter opts for an overall strategy of A/ Repetition, and then, in connection with "gravøl", she decides to employ a different strategy. This time the strategy is E2/ Paraphrastic Substitution. In her rendition, she seems to be aware of (1) the potential meaning of "gravøl" (informal gathering after the burial, which involves the drinking of something), possibly (2) that the co-text comprises a series of funeral metaphors, and (3) that the intention here is ironical. 
11)

Mens jerntæppet brasede sammen i øst

kunne man i alverdens medier se Gorbatjov drikke gravøl i vest. (6.21)

(6.25) Det var tydeligt at Mikhail Gorbatjov var tilfreds [..]

As the Iron Curtain fell in eastern Europe it was possible to see Gorbachev drinking the funeral celebratory drink in the west. (6.29)

\subsection{Looking for Norms}

In examples 10) and 11), the underlying norm seems to dictate that interpreters should copy the formal features of the source text if at all possible, ie adequacy as initial norm. This is so even if the group-I interpreter is unable to carry it through. However, the following performance (by another group-II interpreter) seems to suggest that this initial norm of adequacy is sometimes superseded by a different kind of norm. In the following case, perhaps the reason is capacity saturation. The norm activated in example 12) may be formulated as follows: An interpreter is allowed to say something which is apparently unrelated to the source-text item in question, ie to employ the strategy of E6/ Substitution Proper, provided that s/he can say something which is contextually plausible. The existence of such a norm is probably peculiar to simultaneous interpreting.

12)

Mens jerntæppet brasede sammen i øst

kunne man

$i$ alverdens medier se Gorbatjov

drikke gravøl i vest. (6.21)

(6.25) Det var tydeligt at Mikhail As the Iron Curtain

collapsed in the east

Gorbatjov var tilfreds

it could be seen

in the media throughout the world that Gorbachev was orientating himself towards the west. (6.29) 


\section{Concluding Remarks}

After a critical review of the set-up of my project, I have shown some of the possibilities that the theory of translational norms may offer in connection with interpreting research. Using my own project as an example, I have exemplified that this methodology may indeed work on interpreting. Needless to say, though, that a lot of work in the field is still necessary before we acquire an extensive knowledge of norms governing interpreting processes. By means of conclusion, I would like to emphasize that the question of norms in interpreting research is both intriguing and worth our attention. Indeed, once we have become aware of the concept of norms in the translational process, it seems hard not to take it into account.

\section{References}

Aarup, Hanne (1993): Theory and Practice in the Teaching of Interpreting. In: Perspectives: Studies in Translatology 2, 167-174. University of Copenhagen: Museum Tusculanum Press.

Dam, Helle Vrønning (1993): Text Condensing in Consecutive Interpreting. In: Gambier, Yves \& Tommola, Jorma (eds.): Translation and Knowledge: SSOTT IV: Scandinavian symposium on translation theory, Turku 4-6 June 1992, 297-313. Turku: Grafia Oy.

Davidsen-Nielsen, Niels \& Claus Færch \& Peter Harder (1982): The Danish Learner. Kent: Antony Taylor.

Delabastita, Dirk (1989): Translation and Mass-communication: Film and T.V. translation as evidence of cultural dynamics. In: Babel 35:4, 193-218.

Delabastita, Dirk (1993): There's a Double Tongue: An investigation into the translation of Shakespeare's wordplay, with special reference to Hamlet. Amsterdam/Atlanta: GA Rodopi.

Dollerup, Cay (1978): Omkring sproglig transmission. University of Copenhagen, Department of English: Anglica et Americana 3.

Dollerup, Cay (1982): An Analysis of some Mechanisms and Strategies in the Translation Process Based on a Study of Translations between Danish and English. In: The [Incorporated] Linguist 21, 162-169.

Dollerup, Cay \& Lena Fluger \& Anne Zoëga (1992): Interpreting and Translation: Two sides of the same coin. In: Hermes 8, 43-53.

Fluger, Lena (1983): Hvor går det galt?. In: Lena Fluger \& Per Anker Jensen \& Anne Zoëga: Tre studier i tolkning. Handelshøjskolen i København: ARK 20, 25-35.

Fluger, Lena \& Anne Zoëga \& Hanne Aarup (1991): Tolkning uden tårer: Konferenceuddannelsen på HHK. Handelshøjskolen i København: ARK 59.

Gile, Daniel (1991): The Processing Capacity Issue in Conference Interpretation. In: Babel 37:1, 15-27. 
Gile, Daniel (1993): Translation/Interpretation and Knowledge. In: Gambier, Yves \& Jorma Tommola (eds.): Translation and Knowledge: SSOTT IV: Scandinavian symposium on translation theory, Turku 4-6 June 1992, 67-86. Turku: Grafia Oy.

Gile, Daniel (1994): Opening up in Interpretation Studies. In: Mary Snell-Hornby \& Franz Pöchacker \& Klaus Kaindl (eds.): Translation Studies an Interdiscipline: Selected papers from the Translation Studies Congress, Vienna 9-12 September 1992, 149-158. Amsterdam/Philadelphia: John Benjamins.

Gile, Daniel (this volume): Interpretation Research: A New Impertus?

Goffman, Erving (1981): Forms of Talk. Oxford: Basil Blackwell.

Harris, Brian (1990): Norms in Interpretation. In: Target 2:1, 115-119.

Hermans, Theo (1991): Translational Norms and Correct Translations. In: Kitty M. van Leuven-Zwart \& Ton Naaijkens (eds.): Translation Studies: The State of the Art: Proceedings of the First James S Holmes Symposium on Translation Studies, 155169. Amsterdam/Atlanta: Rodopi.

Jacobsen, Henrik Galberg \& Peder Skyum-Nielsen (1988): Erhvervsdansk: Grundbog 2. rev. udg. København.

Jansen, Peter (forthcoming): The Role of the Interpreter in Dutch Courtroom: Interaction and the Impact of the Situation on Translational Norms. In: Clem Robyns \& Peter Jansen (eds.): Selected Papers of the CERA Research Seminar in Translation Studies 1993-1994. K.U. Leuven.

Leech, Geoffrey N. (1987): Meaning and the English Verb. Longman.

Lenstrup, Rita \& Anne Zoëga (1987): Nogle formidlingsstrategier ved tolkning og oversattelse. Handelshøjskolen i København: ARK 33.

Longman Dictionary of English Language and Culture: With colour illustrations (1992). Longman Group UK Limited.

Mondahl, Margrethe (1989): On learners' Use of Linguistic Knowledge in Relation to a Translation Task: An empirical study of ten Danish learners' use of explicit and implicit linguistic knowledge in expressions of future reference in English. Handelshøjskolen i København, Inst. for Engelsk: Licentiatafhandling.

Pöchhacker, Franz (1992): The Role of Theory in Simultaneous Interpreting. In: Cay Dollerup \& Anne Loddegaard (eds.): Teaching Translation and Interpreting: Training, Talent and Experience, 211-220. John Benjamins Publishing Company.

Pöchhacker, Franz (1993): On the Science of Interpretation. In: The Interpreters' Newsletter 5, 52-59. Trieste.

Pöchhacker, Franz (this volume): Simultaneous Interpreting: A functionalist perspective.

Schjoldager, Anne (1994a): Interpreting Research and the 'Manipulation School' of Translation Studies. In: Hermes 12, 65-89.

Schjoldager, Anne (1994b): An Exploratory Study of Translational Norms in Simultaneous Interpreting (SI). Poster presented at The International Conference on Interpreting, Turku, 25-27 August 1994. 
Schjoldager, Anne (forthcoming): CERA Paper: An Exploratory Study of Translational Norms in Simultaneous Interpreting: Methodological reflections. In: Clem Robyns \& Peter Jansen (eds.): Selected Papers of the CERA Research Seminar in Translation Studies 1993-1994. K.U. Leuven.

Seleskovitch, Danica (1978a): Interpreting for International Conferences. Washington D.C.: Pen and Booth.

Seleskovitch, Danica (1978b): Language and Cognition. In: David Gerver \& H. Wallace Sinaiko (eds.): Language Interpretation and Communication, 333-341. New York/London: Plenum Press.

Shlesinger, Miriam (1989): Extending the Theory of Translation to Interpretation: Norms as a case in point. In: Target 1:1, 111-115.

Shlesinger, Miriam (1990): Factors Affecting the Applicability of the Oral-literate Continuum to Interpretation Research. In: Maya Fruchtman \& Menahem Zevi Kaddari (eds.): Stylistics and the Literary Text: A special issue, 149-56. Bar-Ilan University Press: Hebrew Linguistics Issue Balsanut 'ivrit 28-29-30.

Shlesinger, Miriam (1994): Intonation in the Production and Perception of Simultaneous Interpretation. In: Lambert, Sylvie \& Moser-Mercer, Barbara (eds.): Bridging the Gap: Empirical research on simultaneous interpreting, 225-236. Amsterdam/Philadelphia: John Benjamins, Benjamins Translation Library.

Toury, Gideon (1978): The Nature and Role of Norms in Literary Translation. In: Gideon Toury (1980), In Search of a Theory of Translation, 51-62. The Porter Institute for Poetics and Semiotics, Tel Aviv University: Academic Press.

Toury, Gideon (1980): In Search of a Theory of Translation. The Porter Institute for Poetics and Semiotics, Tel Aviv University: Academic Press.

Vanderauwera, Ria (1982): Review: Gideon Toury 'In Search of a Theory of Translation'. In: André Lefevere \& Kenneth David Jackson (eds.): The Art and Science of Translation, 177-179. The University of Michigan: Dispositio 7:19-2021.

Wadensjö, Cecilia (1992): Interpreting as Interaction - On Dialogue Interpreting in Immigration Hearings and Medical Encounters (Dissertation). Linköping University, Department og Communication Studies.

Wadensjö, Cecilia (this volume): Dialogue Interpreting and the Distribution of Responsibility.

Østergaard, Frede (1979): The Progressive Aspect in Danish. In: Thore Pettersson (ed.): Aspectology: Workshop at the Fifth Scandinavian Conference of Linguistics, Frostvallen April 27-29 1979, 89-109. Almqvist \& Wiksell International. 
